\title{
Who are the big-spending beachgoers and what is important for them?
}

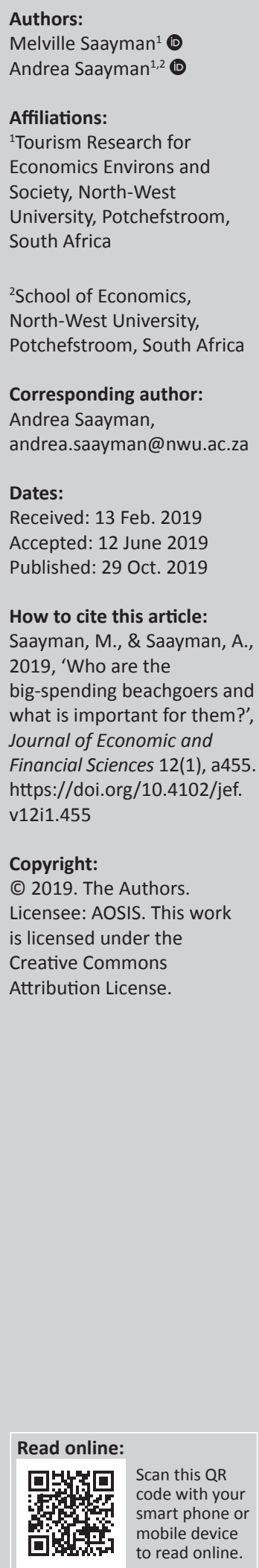

Orientation: Beaches attract millions of visitors every year and this has an impact not only on the economy, the environment and the local community but also on current and future beachgoers.

Research purpose: The aim of the article is to use expenditure-based segmentation to gain a greater understanding of beach visitor spending in order to identify different markets and the aspects they deem important.

Motivation for the study: Although South Africa has a coastline of approximately $3900 \mathrm{~km}$, little is known about the beachgoer to these beaches. This article contributes to the quantification of the economic benefits stemming from beach tourism and in understanding the factors that drive beach visitation.

Research approach/design and method: During 2017/18, beachgoers to eight beaches in South Africa were surveyed and 1138 questionnaires were gathered. Using cluster analysis, four segments of beachgoers were identified. The differences between the various segments were explored by using analysis of variance and Pearson's chi-square.

Main findings: The high-spending markets can be distinguished by language, level of education and age, while sunbathing and relaxation are key beach activities. Six key motives for visiting beaches were identified. High-spending markets tend to visit Blue Flag beaches that offer good bathing conditions.

Practical/managerial implications: This research identified four segments of visitors to South African beaches, ranging from low-spending locals to high-spending mixed market beachgoers. There are distinct differences between the segments, but important to all segments are the environment qualities of the beach in terms of both cleanliness and beach safety.

Contribution/value-add: The research, therefore, concludes that two the main threats to beach tourism and destinations are (1) pollution of the oceans and (2) global warming.

Keywords: marine tourism; expenditure-based segmentation; cluster analysis; South Africa; travel motives.

\section{Introduction}

Tourism constitutes the world's largest commercial service sector industry and beaches are considered the major factor in this tourism market (Houston 2002; Phillips \& House 2009). In fact, Lucrezi and Saayman (2014) state that the beach is the prototypical scene of recreation and leisure, and worldwide it supports more tourism trade than any other environment. Coastal or marine tourism, in which beaches play a critical role, are both among the oldest and largest segments of the tourism industry (Saayman 2017). In this context, Houston (2008) and Leatherman (1997) confirm that beaches are the leading tourist destinations in the USA. As an example, Miami's beaches attract twice as many tourists per year as the Grand Canyon (4.3 million), Yellowstone National Park (2.9 million) and Yosemite National Park (3.2 million) (Houston 2008). The same situation is evident in many other countries, especially island economies around the world.

Lucrezi and Saayman (2014) and Tudor and Williams (2006) highlight the fact that beach tourism's huge economic value makes it imperative for beach managers to take account of the platform of preferences, priorities, spending and motivations that beachgoers bring to their choice of holiday destination. A conceptual marine tourism framework (MTF) was developed to assist researchers in identifying the relevant relationship and the aspects that influence the final outcome of increased spending by investors and stakeholders (see Figure 1). This article focuses on the nonconsumptive activity of beach-going and specifically the factors that influence spending of 


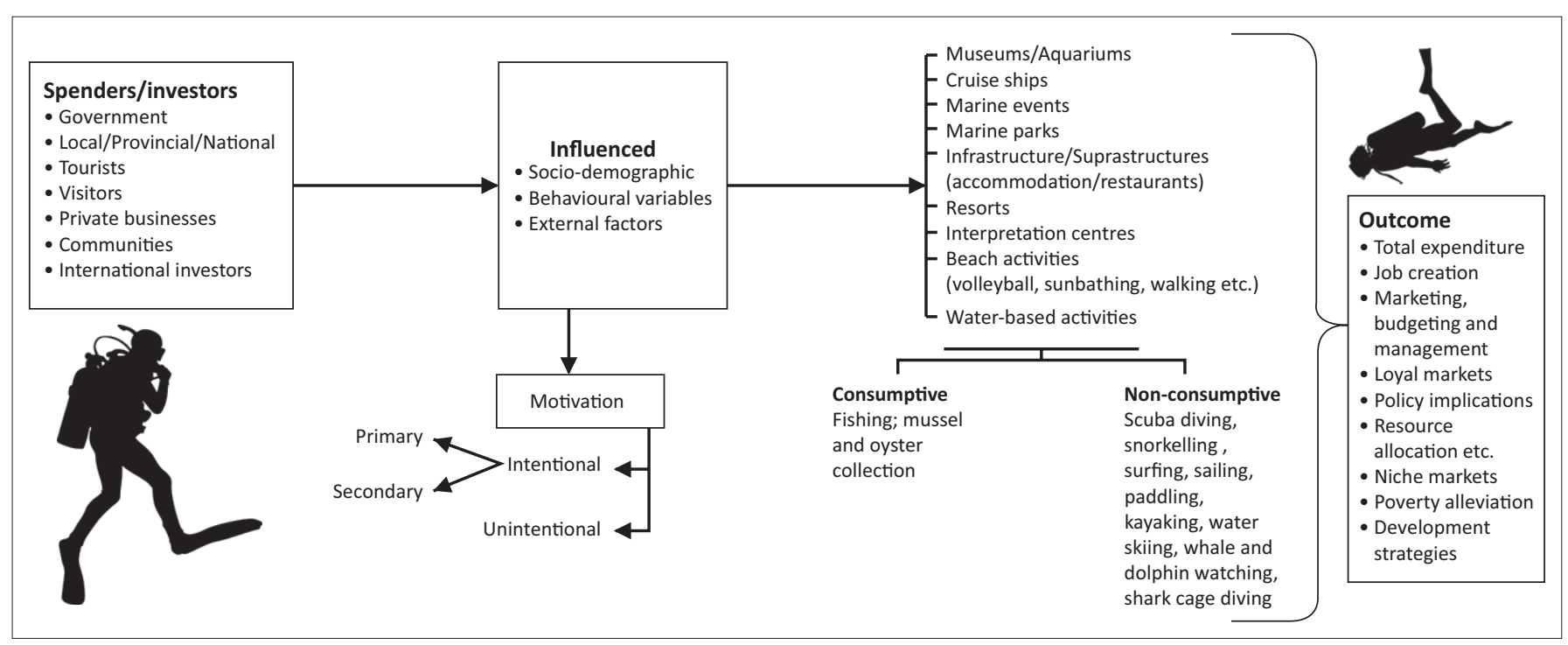

Source: Saayman, M., 2017, 'Blue growth and tourism', Keynote address at the 6th IATE conference, Rimini, Italy, June 2017

FIGURE 1: Conceptual marine tourism framework.

beachgoers, with the aim to advise beach management on development and marketing strategies.

The conceptual MTF highlights the fact that many stakeholders spend money in some way or another; this article focusses on the spending patterns of beach tourists / visitors. Their spending is influenced by socio-demographic and behavioural variables as well as external factors, for example how well the beach is known or promoted, the distance to the beach, and what the beach has to offer in terms of activities. These external factors can be viewed as 'pull factors' that entice beachgoers to choose this specific beach, and therefore include unique beach attributes. Interestingly, most studies in this field of research show that behavioural variables (which include group size, nights spent, frequency of travel and activity participation) have a greater impact on spending than socio-demographic variables (Saayman \& Saayman 2018). In addition, the motivation for visiting the beach can also influence spending (Kruger, Saayman \& Ellis 2010a). Beachgoers can visit beaches intentionally as a primary or key motive or as a secondary motive. Many do it unintentionally when they visit a destination and end up spending time and money while visiting a beach. Finally, the spending by the relevant stakeholders, as indicated in Figure 1, has an impact on total expenditure, job creation, poverty alleviation et cetera.

Beaches are in many instances seen as icons, a view that is also true for island destinations; this contributes to their value and is the reason why so many people visit beaches each year (James 2000). In this regard, South Africa is no different. The country has a coastline of approximately 3000 $\mathrm{km}$, of which almost half is characterised by sandy beaches (Harris et al. 2011). In addition, 23\% of its shoreline is conserved as protected marine areas (Harris et al. 2011). Despite the popularity of beaches and beach tourism, very little research on this topic has been conducted, especially on the spending behaviour and profile of beach tourists. In developing countries, even less research has been carried out.
Therefore, the purpose of this article is to apply expenditurebased segmentation to beach tourists visiting South African beaches. The article contributes to the quantification of the economic benefits stemming from beach tourism and in understanding the factors that drive beach visitation.

\section{Literature review}

The reason for applying expenditure-based segmentation is well documented in the literature. In this regard, Lima, Eusébio and Kastenholz (2012) confirm that segmenting the market according to visitor/tourist expenditure patterns, profiling these segments in terms of socio-demographic and travel behaviour and finally evaluating a destination's capacity to attract and satisfy each segment are paramount in developing strategies to enhance the contribution of tourism to local economic development and therefore poverty alleviation. These authors argue that doubt still exists about the role that tourism plays in local economic development. In developing countries, it is very important to focus on tourism's contribution to development and especially poverty alleviation.

Therefore, the purpose of expenditure segmentation is motivated by the following reasons (Botha et al. 2011; Saayman \& Saayman 2006, 2018; Wilton \& Nickerson 2006): It helps to evaluate expenditure patterns critically; It helps in identifying the more lucrative markets; It gives a better understanding and application of behavioural characteristics that influence visitor spending; It highlights visitor loyalty, which is compounded by repeat visits; It distinguishes clearly between different spending categories; It can provide valuable information to address poverty alleviation; It can assist destination managers in demonstrating the economic benefits that visitors produce in host communities; It helps in giving a greater understanding of beach tourists' spending behaviour; It offers useful information for policy formulation; It helps in identifying niche markets; It helps to report on 
market changes and needs; It increases the cost effectiveness of marketing, and it assists in developing the right packages and product development decisions.

Although studies on expenditure patterns among visitors and tourists have been valued by planners, marketers and business managers, studies on expenditures remain limited (Jang et al. 2004; Shani et al. 2010; Soteriades \& Arvanitis 2006). Such data not only provide a good input in market segmentation, but can also lead to increased revenue. In this regard, Saayman and Saayman (2018) highlight the fact that visitor spending is the first input in an economic impact assessment and also serves as a central component in determining profitability.

Market segmentation is seen as one of the most critical concepts for businesses and is based on the premise that heterogeneity in demand functions exist in such a way that market demand can be disaggregated into segments with distinct demand functions (Dickson \& Ginter 1987; Shani et al. 2010). These segments can then be used to develop the right product and market mix for each segment.

Based on the literature, the first attempt at expenditure-based segmentation was done by Pizam and Reichel (1979), who used the 1972 U.S. Consumer Expenditure Survey in which they identified two categories of spenders, namely little and big spenders. Since then, a variety of spender categories have been identified, for example light, medium and heavy spenders (Craggs \& Schofield 2009; Mok \& Iverson 2000; Shani et al. 2010; Spotts \& Mahoney 1991); low, medium and high spenders (Dixon et al. 2012); low and high spenders (Kruger, Saayman \& Saayman 2010b; Saayman, Saayman \& Joubert 2012); and low, medium, high-medium and high spenders (Botha et al. 2011).

Although most of the studies conducted on expenditurebased segmentation focus on a combination of low to high spenders, it seems that when it comes to specialised markets, different combinations exist and therefore a more detailed distinction between expenditure groups is required. For example, on the topic of mountain tourists, Lima et al. (2012) identified four segments, namely high and medium spenders who are lodging-orientated, activities-orientated, and foodand shopping-orientated. Research by Saayman and Saayman (2018) on expenditure-based segmentation of scuba divers identified six markets, namely rescue divers, intercontinental spending divers, international dive masters, new local divers, intercontinental advanced divers and local instructors. Within these markets, there was a spectrum of high to low spenders. Dixon et al. (2012) mentioned that destinations and tourism-related businesses are interested in attracting 'quality' tourists, with 'quality' generally referring to highspending tourists. For this reason, it is important to identify the socio-demographic, behavioural and motivational characteristics and expenditure of these 'quality' tourists as well as the external factors that are important to them.
According to the literature review, high spenders can be distinguished from the medium and low segments by the following socio-demographic characteristics:

Firstly, they are better educated, having obtained higher levels of education, according to Hong et al. (2005), Kuo and Lu (2013), Pizam and Reichel (1979) and Snowball and Willis (2006:29). However, research by Shani et al. (2010) and Jang, Morrison and O'Leary (2002) find little support that education influences spending.

Secondly, they are employed in higher-income occupations (Cannon \& Ford 2002; Kruger 2010; Kuo \& Lu 2013; Saayman \& Krugell 2009; Saayman \& Saayman 2006; Saayman et al. 2012; Snowball \& Willis 2006; Thrane 2002; Woodside, Cook \& Mindak 1987), although Spotts and Mahoney (1991) found the opposite.

Thirdly, they are older (Cal, Hong \& Morrison 1995; Craggs \& Schofield 2009; Kastenholz 2005:563; Kruger 2009, 2010; Kuo \& Lu 2013; Mehmetoglu 2007; Perez \& Sampol 2000; Saayman et al. 2009; Thrane 2002:284; Wang et al. 2006). Research by Shani et al. (2010) did not find any significant differences between age groups and spending.

Fourthly, they often stem from a specific province, country or place of residence (Kruger et al. 2010b; Saayman et al. 2012; Brida \& Scuderi 2013) and they are from international markets (Saayman \& Saayman 2006, 2018).

Fifthly, from a gender perspective, it is mostly found that females spend more than males (Craggs \& Schofield 2009; Kruger 2009; Letho et al. 2004; Saayman et al. 2012).

Finally, language also plays a role in distinguishing high spenders from the rest in a multilingual destination or country (typically South Africa) (Saayman \& Krugell 2009; Saayman et al. 2012).

The behavioural variables that distinguish high spenders from the rest include the following:

Firstly, they travel specifically or primarily to visit the specific destination or an event (Botha et al. 2011; Craggs \& Schofield 2009; Mehmetoglu 2007:213; Saayman \& Saayman 2006:220).

Secondly, some researchers find that they travel in smaller groups (Kruger 2010:50; Mok \& Iverson 2000:303-305; Saayman \& Saayman 2006:220), although others such as Jang et al. (2004), Jang et al. (2002), Lee (2001), Saayman et al. (2008:17) and Spotts and Mahoney (1991:24) revealed the exact opposite and concluded that high spenders tend to travel in larger groups.

Thirdly, they stay longer at the destination (Downward \& Lumsdon 2004; Kruger et al. 2010b; Mehmetoglu 2007; Mok \& Iverson 2000; Seiler et al. 2002; Shani et al. 2010; Spotts \& Mahoney 1991:24; Thrane 2002). 
Fourthly, they travel longer distances to reach the destination (Cannon \& Ford 2002:263; Lee 2001:659; Pouta, Neuvonen \& Sievanen 2006:132; Saayman et al. 2008:17).

Fifthly, the frequency of visits or participation indicates that high or big spenders are those who visit or participate more frequently (Botha et al. 2011; Dixon et al. 2012; Saayman \& Saayman 2018; Shani et al. 2010; Wang 2004). However, Alegre and Juaneda (2006), Jang et al. (2004), Kruger et al. (2010a), Lee et al. (2006) and Oppermann (1996) found firsttime visitors to be the higher spenders than repeat visitors.

In the sixth instance, the mode of transport also influences spending with Shani et al. (2010) finding that those who travel by car are bigger spenders than those travelling by bus or train. In addition, the type of accommodation distinguishes high or big spenders from the rest (Kruger et al. 2010b).

Besides the above socio-demographic and behavioural variables, Saayman and Saayman (2012) found that high spenders have a greater environmental awareness compared to the rest.

Most of the studies on expenditure-based segmentation applied one dependent variable. However, Sung, Morrison and O'Leary (2000) state that the use of a combination of variables to segment a market is preferred. This is supported by the notion that a variety of variables influences visitor spending (Craggs \& Schofield 2009; Kruger et al. 2010b). The literature revealed that only a few studies in this field applied a combination of variables as opposed to using only one variable (Saayman \& Saayman 2018). Spending is one of the most important variables, since it determines profitability and shows the impact that the spending has on regional economies (Frechtling 2006). Lima et al. (2012) state that visitor expenditure is the main focus, showing the economic impact of tourism on a destination's economy; the higher the expenditure, the greater the economic impact. From a destination manager's point of view, the destination needs to decide not only how many visitors it wants to attract, but what kind of visitors are favourable and should be retained. With the above in mind, we have used a combination of variables in identifying clusters. Over and above expenditure, we have also included international versus local residents and visitors from the rest of South Africa in our analysis.

\section{Research method \\ Questionnaire and survey}

The research followed a quantitative, descriptive and non-experimental design, using a structured questionnaire survey that targets beachgoers. The questionnaire was based on the works of Kruger (2010), Kruger et al. (2010b), Lee (2001) and Tudor and Williams (2006) and consisted of three sections. The first section focussed on the socio-demographic and spending behaviour of beachgoers. The second section, which was not used in this research article, focussed on tourism-shark interactions. The third section assessed the motives and beach choice decisions. Only sections one and three were used in the analysis.

The questionnaire included both close-ended and openended questions on socio-demographic, behavioural and local beach information. The socio-demographic questions assessed the gender, age, marital status, occupation, level of education and origin of the respondent. They also included eight spending categories, namely accommodation, shopping, restaurants, transport, activities, entertainment, curios/souvenirs and other in order to get a more detailed picture of spending behaviour. The respondent was also asked to indicate the number of people that this spending accounts for, since it is important to assess spending per person.

Besides the socio-demographic questions, questions on behaviour were also assessed, including travel group size and nights spent close to the beach. The respondents were asked to indicate why they visit the beach, with the following activity participation categories provided: sunbathing, swimming, surfing, walking and other. In addition, 22 motivational statements for choosing the specific beach were tested on a four-point Likert scale, ranging from $1=$ disagree to 4 = strongly agree. The motivational statements were adapted from the study of Lucrezi and Saayman (2014). Furthermore, a number of open-ended questions assessed the external factors that attract them to the beach, including to indicate what they look for in a beach and what the greatest risks are when going to the beach. The responses were coded and the most important 'needs' and 'risks' in beach-going were identified.

The questionnaires were randomly distributed on the beaches by a group of five trained field workers at the different destinations. Eight locations in South Africa were selected for this study (see Figure 2), namely Durban and Ballito in KwaZulu-Natal; Jeffreys Bay and Port Elizabeth in the

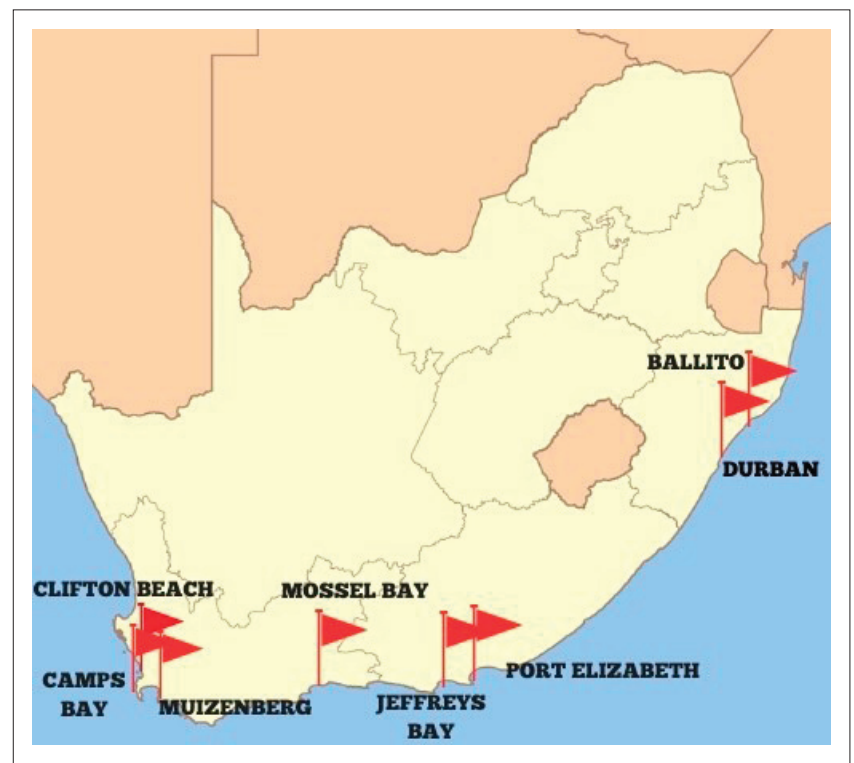

FIGURE 2: Map indication location of beaches. 
Eastern Cape province of South Africa; and Mossel Bay, Muizenberg, Camps Bay and Clifton beach in the Western Cape province. These locations were chosen as they are the most popular beaches in the country. The survey ran during the months of December 2016 to July 2018. A total of 1138 questionnaires were returned. Data were pooled and analysed using the IBM SPSS25 software.

\section{Analysis}

To identify high-spending and low-spending beachgoers, a two-step clustering approach was used. In general, there are two approaches to cluster analysis, namely hierarchical and non-hierarchical methods. Hierarchical methods can accommodate scale (or numeric) data and use distance measures to form clusters of similar cases. Non-hierarchical methods require the prior selection of the optimum number of clusters and can only form clusters by using the same type of data (i.e. nominal, ordinal or numeric) (Norušis 2012). This method is quite sensitive to outliers. A relatively new procedure, namely two-step clustering, combines hierarchical and non-hierarchical methods and can therefore accommodate scale and ordinal data in the same model. It has the additional advantage that it chooses the optimal number of clusters (similar to hierarchical methods) (Shih, Jheng \& Lai 2010).

Since the variable of interest is expenditure (a numeric variable) per person, which can be prone to outliers, additional variables were included to form sensible clusters, namely whether or not a respondent is a South African citizen and whether or not he/she is a local resident (i.e. international vs. local resident vs. visitors from the rest of South Africa). Since total expenditure per person was determined as the sum of spending on different aspects of the trip (accommodation, transport, food etc.) and then divided by the number of persons for which the respondent is financially responsible during the trip, only questionnaires that had complete information on these could be used. This rendered an adjusted sample of approximately 600 .

Secondly, the motivational statements were reduced by using principal component analysis. The Kaiser-Meyer-Olkin measure indicated that the sample was sufficient to allow principal component analysis (KMO of 0.884), while Bartlett's test of sphericity was also significant $\left(\chi^{2}=1455.005\right.$; prob $<0.0001)$, which signified that distinct and reliable factors could be extracted. Kaiser's criterion was followed and only factors with an eigenvalue greater than unity were extracted. In addition, oblique rotation was used in the extraction of the factor loadings in order to discriminate better between the factors (Field 2009). Factor scores were calculated using the Anderson-Rubin method, which delivers uncorrelated, standardised scores.

To explore the differences between the clusters, one-way analysis of variance (ANOVA) was used for the scale variables. Both Bonferroni's and Tamhane's T2 post hoc tests were performed to determine pairwise differences between clusters, with the Bonferroni test controlling for Type 1 errors and Tahmane's test being more powerful when groups are unequal in size. To explore differences between clusters when the variables are nominal or ordinal, Person's chi-square was used, as well as Cramer's V as an approximate effect size (Field 2009).

\section{Ethical considerations}

This research project received ethical clearance and the ethics project number EMS2016/11/04-02/19 was assigned. This acceptance deems the proposed research as being of minimal risk, granted that all requirements of anonymity, confidentiality and informed consent are met, which was adhered to during the fieldwork.

\section{Results}

The results are presented in three sections: first, the results of the two-step cluster analysis, followed by the results of the principal component analysis, and then an exploration of the differences between clusters, as explained above. A brief description of the sample is firstly provided (the data summary tables can be found in Appendix 1).

The average age of the respondents in the sample was 34 years old. Most of the respondents (59\%) were female and most respondents (49\%) were English-speaking. A total of $34 \%$ of the respondents had at least a diploma or degree, with $20.5 \%$ also in possession of post-graduate qualifications. The majority of respondents (53\%) were single and most respondents were in paid occupations (65\%).

In terms of the origin of respondents, 35\% were foreigners, whereas 20\% were from the Western Cape province - one of the provinces in which a number of beaches are located. A large percentage (15.4\%) of respondents came from Gauteng, which is a landlocked province; these beachgoers travel to the beach mainly during school holidays. Less than one-quarter of the sample are locals living in the beach vicinity.

Respondents travel in groups of between three and four (an average of 3.6 members per group), spend an average of 14 nights or two weeks at the beach (note that nights spent at the beach for locals were recorded as not applicable), and spend just more than ZAR7000 per person while visiting the beach. As can be expected, people visit the beach more regularly during summer months than winter months.

\section{Cluster analysis}

The two-step cluster analysis with numeric input of spending per person and the categorical inputs of South African versus non-South African residents, as well as locals versus nonlocal residents of the beach area, delivered four distinct clusters. The clusters and their membership are summarised in Table 1. Three large clusters and one smaller cluster (cluster 2) were identified. The cluster with the most members 
TABLE 1: Results of the cluster analysis.

\begin{tabular}{|c|c|c|c|c|c|c|}
\hline Cluster & $N$ & Per cent & Mean spending & Standard deviation & Non-RSA & Local residents \\
\hline 1 - local low spenders & 128 & 21.6 & 3571.74 & 5453.62 & 0 & 128 \\
\hline $2-$ mixed high spenders & 31 & 5.2 & 43376.02 & 34134.57 & 26 & 13 \\
\hline 3 -foreigners & 184 & 31.1 & 7114.29 & 7598.06 & 184 & 0 \\
\hline 4 -South Africans & 249 & 42.1 & 4127.95 & 4640.64 & 0 & 0 \\
\hline Combined & 592 & 100 & 6991.10 & 12956.92 & 210 & 141 \\
\hline
\end{tabular}

is cluster 4 (249 members, or $42.1 \%$ of the sample). The average spending per person of this cluster is just more than ZAR4000, and this cluster is exclusively South Africans who are not local residents of the beach area.

The second largest cluster in terms of membership is cluster 3 (184 members; i.e. $31.1 \%$ of the sample) and this cluster consists exclusively of foreign tourists visiting South African beaches. The cluster has a mean spending per person of just more than ZAR7000. Cluster 1 is the third largest with $21.6 \%$ of the members (128 respondents) belonging to this cluster. It is the cluster with the lowest spending per person (ZAR3571.74) and consists exclusively of local residents of the various beach areas.

Finally, the smallest cluster is cluster 2 , with only $5.2 \%$ of the total membership (31 respondents); this cluster boasts the highest-spending per person - more than ZAR40 000. The cluster is mixed in terms of the origin of its members and is the only cluster that contains members of all three origins - international, South African and local residents. Figure 3 below indicates the silhouette measure of cohesion and separation, which is close to 1 , and therefore the cluster quality is excellent, meaning that the members within a cluster are very similar, but very different from those in other clusters.

\section{Principal component analysis}

The motivational statements were subjected to a principal component analysis and six factors with eigenvalues greater than unity were identified, which explains $58.425 \%$ of the variance. The different components are identified in Table 2, which also shows Cronbach's alpha and the mean of each component.

From Table 2, it is clear that the factor that scores the highest (3.076 out of 4 ) is factor 2 and that this reflects the beach quality, namely its safety, cleanliness and management. The second most important motivation is factor 6 (2.995 out of 4), which contains statements on the accessibility of the beach, closely followed by factor 3 (with a mean score of 2.957 out of 4), which captures aspects of the beachgoers' connectivity with the beach. The important escape motive found in most travel literature also forms part of this factor.

Factor 5 also scores above 2.9 out of 4 , indicating that it is an important motive for going to the specific beach. This factor contains two aspects, namely the Blue Flag status of the beach and its popularity. Factor 1 contains statements on the swimming experience that the beach offers. It has a mean

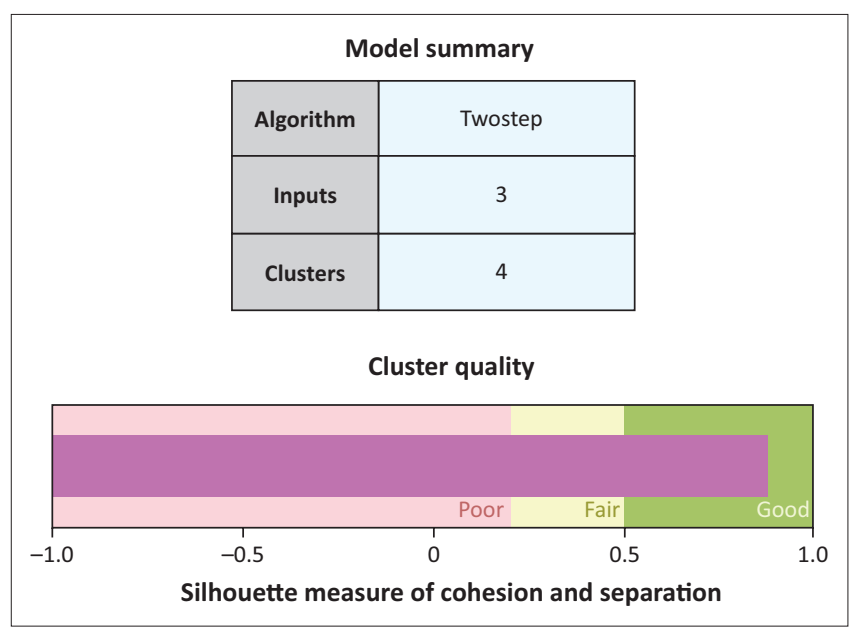

FIGURE 3: Model summary.

score of 2.746 out of 4 . The least important motive for visiting the specific beach is factor 4 , has a mean score of 2.634 out of 4 and the statements contained in this factor incorporate the activities offered by the beach.

\section{Cluster differences}

To explore the uniqueness of each cluster, the various socio-demographic, travel behavioural and motivational components (defined above) for each cluster were summarised by using means (for scale data) and frequencies (for categorical data). These are summarised in Table 3 and although there are clear differences between the various clusters, the significance of these were determined by using ANOVA and Pearson's chi-square test (the ANOVA test results as well as the chi-squared results are found in Appendix 1).

In terms of socio-demographic variables, there is no significant difference in the gender of each cluster, although there is a significant difference in their home language $(p<0.01$ with effect size of 0.409$)$. Clusters 2 and 3 contain beachgoers who do not predominantly speak Afrikaans or English, whereas these languages are spoken by more than $85 \%$ of the members in clusters 1 and 4 . The difference between the average age of clusters 3 and 4 is also significant $(p<0.05)$, with cluster 3 consisting of younger members than cluster 4 . Not surprisingly, the origin of the respondents is significantly different between clusters $(p<0.01$; effect size of 0.641). What is interesting, though, is that cluster 2 contains no members from KwaZulu-Natal province - one of the provinces that boast good beach conditions year-round. Furthermore, the differences in educational profiles between the various clusters are significant $(p<0.05$; effect size 0.136$)$, 
TABLE 2: Results of the principal component analysis. Variables

1

123

\section{It has good swimming conditions}

Swimming experience Beach quality Beach connectivity Beach activities

The different types of people who come here

$\begin{array}{cc}0.643 & - \\ 0.426 & - \\ 0.746 & - \\ 0.579 & - \\ - & 0.652 \\ - & 0.709 \\ - & 0.540 \\ - & 0.825\end{array}$

It provides safe swimming conditions

The sea produces good waves

The water quality is overall good

The beach is well managed

The beach is clean

I feel a special connection with this beach

To break away from routine

I had good previous experiences

It is not too crowded

0.552

There is more than enough parking

There is a high number of water activities

Various events are hosted here

I wanted to explore new places

The beach has Blue Flag status

The beach is popular

The beach has a beautiful natural setting

Many people come to this beach

The beach is close

It is easily accessible

Mean

e

Cronbach's alpha

2.746

0.762

$\begin{array}{cc}- & 0.552 \\ - & 0.905 \\ - & 0.696 \\ - & 0.543\end{array}$

Extraction method: Principal component analysis; Rotation method: Promax with Kaiser normalisation.

TABLE 3: Cluster descriptives and differences.

\begin{tabular}{|c|c|c|c|c|}
\hline Variable & Cluster 1: Local low spenders & Cluster 2: Mixed high spenders & Cluster 3: Foreigners & Cluster 4: South Africans \\
\hline Female & $57.00 \%$ (predominantly female) & $48.40 \%$ (predominantly male) & $59.20 \%$ (predominantly female) & $58.60 \%$ (predominantly female) \\
\hline Average age & 35.21 years & 31.9 years & 32.05 years $* *$ & 35.29 years $* *$ \\
\hline Language & $\begin{array}{l}\text { English - } 65.6 \% \text {; Afrikaans - } \\
21.6 \% * * *\end{array}$ & English $-41.9 \%$; Other $-58.1 \% * * *$ & English $-34.1 \%$; Other $-65.9 \% * * *$ & $\begin{array}{l}\text { English - 52.0\%; Afrikaans - } \\
33.7 \% * * *\end{array}$ \\
\hline Education & $\begin{array}{l}\text { Diploma/Degree - 34.4\%; } \\
\text { Matric }-24.0 \% * *\end{array}$ & $\begin{array}{l}\text { Post-graduate }-31.0 \% \text {; Diploma/ } \\
\text { Degree }-27.6 \% * *\end{array}$ & $\begin{array}{l}\text { Diploma/Degree }-41.3 \% \\
\text { Post-graduate }-22.3 \% * *\end{array}$ & $\begin{array}{l}\text { Diploma/Degree - 29.8\%; } \\
\text { Matric-26.9\%** }\end{array}$ \\
\hline Province/Country & $43.8 \%$ WC; $32.0 \% \mathrm{KZN} ; 22.7 \%$ EC*** & $83.9 \%$ Non-RSA; $9.7 \%$ WC*** & $100 \%$ Non-RSA $* * *$ & $\begin{array}{l}33.3 \% \text { Gauteng; } 23.7 \% \text { WC; } 16.9 \% \\
\text { EC*** }\end{array}$ \\
\hline Marital status & $5.4 \%$ Single; $43.3 \%$ Married $* * *$ & $64.5 \%$ Single; $25.8 \%$ Married $* * *$ & $63.9 \%$ Single; $32.2 \%$ Married $* * *$ & $46.6 \%$ Single; $41.4 \%$ Married $* * *$ \\
\hline Occupation & $66.4 \%$ Paid worker; $19.5 \%$ Student & $41.4 \%$ Paid worker; $41.4 \%$ Student & $67.4 \%$ Paid worker; $22.7 \%$ Student & $66.7 \%$ Paid worker; $16.5 \%$ Student \\
\hline Blue Flag beach & $68.80 \% * * *$ & $90.30 \% * * *$ & $96.70 \% * * *$ & $70.30 \% * * *$ \\
\hline Average group size & 3.68 & 2.96 & 3.51 & 3.80 \\
\hline $\begin{array}{l}\text { Average number of } \\
\text { nights spent }\end{array}$ & $\mathrm{n} / \mathrm{a} * * *$ & 75 & 13.62 & 9.73 \\
\hline Reason for beach visit & $\begin{array}{l}\text { Sunbathing }-51.6 \% * * * ; \text { Swimming } \\
-66.4 \% * * * ; \text { Surfing }-25.8 \% * * * ; \\
\text { Walking }-65.6 \% * * * ; \text { Sport }- \\
5.5 \% * * ; \text { Relaxation }-1.6 \% *\end{array}$ & $\begin{array}{l}\text { Sunbathing }-77.4 \% * * * ; \text { Swimming } \\
-45.2 \% * * * \text { Surfing }-6.5 \% * * * ; \\
\text { Walking }-61.3 \% * * * ; \text { Sport }-0 \% * * ; \\
\text { Relaxation }-9.7 \% *\end{array}$ & $\begin{array}{l}\text { Sunbathing }-80.4 \% * * * ; \text { Swimming } \\
-38.0 \% * * * ; \text { Surfing }-10.9 \% * * * ; \\
\text { Walking }-40.2 \% * * * ; \text { Sport - } \\
0.5 \% \text { * } \%^{* *} \text {; Relaxation }-2.7 \%\end{array}$ & $\begin{array}{l}\text { Sunbathing }-49.4 \% * * * ; \text { Swimming } \\
-62.7 \% * * * \text { S Surfing }-14.5 \% * * * ; \\
\text { Walking }-65.9 \% * * * ; \text { Sport - } \\
2.4 \% * * \text {; Relaxation }-2.0 \% *\end{array}$ \\
\hline $\begin{array}{l}\text { Three most important } \\
\text { things a beach needs }\end{array}$ & $\begin{array}{l}\text { Cleanliness }-38.3 \% \text {; Good conditions } \\
-35.2 \% * * * ; \text { Safety }-30.5 \% * * *\end{array}$ & $\begin{array}{l}\text { Good conditions }-41.9 \% * * * ; \\
\text { Cleanliness }-25.8 \% \text {; Not crowded } \\
-19.4 \% * *\end{array}$ & $\begin{array}{l}\text { Good conditions }-42.4 \% * * * \\
\text { Cleanliness }-29.9 \% \text {; Not crowded } \\
-22.3 \% * *\end{array}$ & $\begin{array}{l}\text { Cleanliness }-36.9 \% \text {; Safety - } \\
29.7 \% * * * ; \text { Good conditions - } \\
29.7 \% * * *\end{array}$ \\
\hline $\begin{array}{l}\text { Three most important } \\
\text { risks at a beach }\end{array}$ & $\begin{array}{l}\text { Theft }-42.2 \% * * * \text {; Sunburn - } \\
10.9 \% * * * ; \text { Sharks }-10.9 \%\end{array}$ & $\begin{array}{l}\text { Theft }-29.0 \% * * * ; \text { Sharks }-22.6 \% \text {; } \\
\text { Sunburn }-19.4 \% * * *\end{array}$ & $\begin{array}{l}\text { Theft }-25.0 \% * * * ; \text { Sunburn - } \\
25.0 \% * * ; \text { Sharks }-16.3 \%\end{array}$ & $\begin{array}{l}\text { Theft }-39.8 \% * * * ; \text { Drowning - } \\
18.1 \% * ; \text { Sharks }-10.8 \%\end{array}$ \\
\hline $\begin{array}{l}\text { Average number of } \\
\text { visits in summer }\end{array}$ & $52.67 * * *$ & 19.41 & 3.94 & 15.97 \\
\hline $\begin{array}{l}\text { Average number of } \\
\text { visits in winter }\end{array}$ & $23.42 * * *$ & 8.10 & 0.83 & 7.33 \\
\hline Motive 1 & $0.39 * *$ & -0.17 & $-0.41 * *$ & 0.12 \\
\hline Motive 2 & -0.12 & 0.02 & 0.11 & -0.02 \\
\hline Motive 3 & 0.06 & 0.16 & -0.11 & 0.03 \\
\hline Motive 4 & -0.03 & -0.32 & 0.07 & 0.00 \\
\hline Motive 5 & -0.05 & 0.09 & -0.16 & $0.13^{* * *}$ \\
\hline Motive 6 & 0.08 & 0.19 & 0.00 & -0.05 \\
\hline
\end{tabular}

$*$, Significant at $10 \%$ level; $* *$, significant at $5 \%$ level; $* * *$, significant at $1 \%$ level. 
with clusters 1 and 4 consisting mainly of less educated members than clusters 2 and 3 . The marital status also differs significantly between clusters ( $p<0.01$; effect size of 0.136 ), with clusters 2 and 3 containing considerable more single members than clusters 1 and 4 .

In terms of their travel behaviour, it is noteworthy that there are no significant differences in the average group size of the clusters. However, since members of cluster 1 are locals and stay in the beach vicinity, they record no nights spent at the beach, while cluster 2 shows an average of more than two months spent at the destination. These differences are significant. Confirming these significant differences are the times that beaches are visited annually in winter and summertime, with cluster 1 visiting beaches more often than any other cluster and members of cluster 3 visiting beaches the least.

The activities that each member takes part in at a beach also differ significantly between clusters. Clusters 2 and 3 tend to visit beaches to sunbathe $(p<0.01$; effect size 0.295$)$, whereas clusters 1 and 4 prefer beaches for swimming ( $p<0.01$; effect size 0.244 ). Clusters 1 and 4 also surf and partake in sporting activities on beaches significantly more than clusters 2 and 3 . Cluster 3 uses beaches the least for walking $(p<0.01$ and effect size of 0.237 ), whereas members of cluster 2 tend to relax on beaches more than any other cluster.

What external factors do the different clusters look for when choosing a beach? This open-ended question was coded according to the responses and four key aspects were mentioned most frequently, namely a clean beach, a safe beach, good beach conditions (waves, water, sand and weather) and a beach that is not crowded. For all the clusters, a clean beach is a priority. Clusters 2 and 3 are more concerned with the conditions on the beach than the other 2 clusters $(p<0.01$; effect size of 0.168$)$, also preferring beaches that are not crowded ( $p<0.05$; effect size of 0.133 ), whereas clusters 1 and 4 are more concerned about safety when choosing a beach $(p<0.01$; effect size of 0.187$)$. In addition, the difference in whether or not the survey was conducted at a Blue Flag beach is significant $(p<0.01$ and effect size of 0.311$)$. More members of clusters 2 and 3 were interviewed at Blue Flag beaches than members of clusters 1 and 4 .

The main risks that beachgoers perceive to be facing at beaches in South Africa are theft, sunburn, drownings and sharks. Although theft is the most important risk for all clusters, the percentage of respondents who identified it as the main risk differs significantly between clusters $(p<0.001$; effect size of 0.153 ), with clusters 1 and 4 being more concerned with theft than the other clusters. Sunburn is the second risk most often identified by members of clusters 1 and 3 , and the second most mentioned risk for members in cluster 2 ( $p<0.05$; effect size of 0.192$)$. Cluster 4 is the only cluster in which drownings feature as a top-three risk; this is significantly different from other clusters $(p<0.1$; effect size of 0.107$)$, but shark attacks are a top-three risk for all clusters (no significant differences).
Finally, in terms of the motives for travelling to beach destinations, there are significant differences between clusters for motives 1 and 5. Cluster 1 values the swimming conditions at the beach (motive 1) significantly higher $(p<0.05)$ than any other cluster. Contrary to this, cluster 3 values swimming conditions as a motive for beach visitation significantly less important $(p<0.01)$ than clusters 1 and 4 . For members of cluster 4, the Blue Flag status and popularity of the beach (motive 5 ) is significantly more important $(p<0.01)$ than for members of cluster 3 .

\section{Findings and implications}

From the results of the analysis, the following findings are eminent:

The first and most important finding from this research is that there are different markets that visit beaches, not only in South Africa, but also worldwide, and these markets exhibit different characteristics and spending behaviour. For South African beaches, four key markets or clusters of beachgoers have been identified that vary in terms of their spending behaviour; they encompass clusters from low spenders to very high spenders, labelled as low-spending locals, mixed high spenders, foreigners and South Africans. The results of the analysis agree to some extent with the research findings by Saayman and Saayman $(2006,2018)$, who found that the international market to destinations is the biggest spending market, although this research showed that the highest-spending cluster is a mixed cluster, followed by the foreigner cluster as the second-highest spenders.

The implication of this finding is that beach managers can use this information in order to focus on the preferences and needs of the high-spending markets. In the South African context, the highest-spending market consists not only of foreigners, but also of South Africans who stay in the vicinity of the beach. Keeping their loyalty and addressing their needs should therefore be a priority for beach managers.

Secondly, this research reveals that there are more behavioural variables and external beach factors influencing spending than socio-demographic variables - a result also found by Saayman and Saayman (2018) for scuba divers in Italy. This also supports the notion by Craggs and Schofield (2009) and Kruger et al. (2010b) that a combination of variables influences spending behaviour. The implication of this finding, together with the first, is useful for beach managers and allows them to package the respective beaches in their marketing material and to have a more focussed approach in attracting what Mak (2004) calls 'quality' tourists.

In comparison with the literature review and the impact that socio-demographic variables have on spending behaviour, the results contradict findings by Craggs and Schofield (2009), Kruger (2010), Letho et al. (2004) and Saayman et al. (2012) that gender plays a role in distinguishing high spenders from low spenders among beachgoers to South African beaches. In terms of age, this research found that the higher spenders 
at beaches are on average younger individuals - a result that has not been found with other destinations and activities. It therefore contradicts findings by Cal et al. (1995), Craggs and Schofield (2009), Kastenholz (2005:563), Kruger (2009, 2010), Kuo and Lu (2013), Mehmetoglu (2007), Perez and Sampol (2000), Saayman and Saayman (2006:217), Saayman et al. (2009), Thrane (2002:284) and Wang et al. (2006). However, the notion that more educated individuals spend more is also supported by the fact that the higher-spending clusters both have more post-graduate qualified beachgoers. This finding supports those of Hong et al. (2005), Kuo and Lu (2013), Pizam and Reichel (1979) and Snowball and Willis (2006:29). Since the clusters were formed by using the origin of the respondents, it is not surprising that both the province or country of origin and home language of respondents differ significantly between clusters.

In comparison with the literature's findings on behavioural variables that influence spending, we found that there are significant differences between the high- and low-spending clusters on a number of aspects. First, members of the lowestspending cluster, which consists exclusively of locals living in the vicinity of the beach, visit the beach significantly more often in both seasons than any of the other clusters' members. This is contradictory to most research on spending at events, where more frequent visitors tend to spend more (see Botha et al. 2011; Dixon et al. 2012; Saayman \& Saayman 2018; Shani et al. 2010; Wang 2004). However, these locals are frequent users of the beach for non-expensive activities such as walking, swimming, surfing and other sport activities. The swimming experience at the beach is the most important motive (Motive 1) for them when visiting a beach. Since South African beaches are non-exclusive and access is free, the beach is a resource that this market uses for recreational purposes. It is therefore not surprising that the members of this market regard safety as a more important aspect of their beach (an external pull factor) than any other market and theft as the main risk facing them. The latter also implies that beach management needs to put strategies in place to ensure safety from criminals for beachgoers by means of visible police and beach guards.

Members of the two higher-spending markets, namely the mixed high spenders and the foreigners, visit the beach mainly for sunbathing purposes, much more than any other market; for the mixed high spenders' connectivity to the beach (Motive 3) and accessibility (Motive 6) are the most important reasons for visiting the beach. Concerning the foreigners, their most important motives for visiting the beach are beach quality (Motive 2) and beach activities (Motive 4). They tend to be less interested in typical South African beach activities such as swimming, sporting events and surfing, although relaxing is a more important reason for beach visits. Although members of the mixed cluster spend more time during both seasons visiting the beach, members of the foreign cluster do not necessarily visit South Africa for its beaches - they are the so-called unintentionally motivated tourists (Saayman 2017). It is therefore not surprising that the average spending of the foreigner cluster is much lower than that of the mixed high spenders. In terms of the importance of external factors pulling visitors to the beach, the higherspending markets are much more attracted to a beach because of its conditions and although theft remains the primary concern, the perceived risk of sunburn is higher than for any of the other markets. It is noteworthy that the highestspending market is also much more concerned about shark attacks than any other cluster.

Members of the lower-spending South African cluster (cluster 4) typically visit the beach over summer holiday times (i.e. December and March) with family and friends. They also use the beach more for swimming and other sporting activities, similar to the low-spending local cluster. It is therefore not surprising that drownings at beaches (as an external factor) are a key concern for this, but no other, market, with drownings due to rip currents and rogue waves a regular occurrence.

Lastly, this research confirms the importance of environmental awareness and the impact thereof on beachgoers and spending, as was highlighted for the first time by Saayman and Saayman in 2012. For all four clusters, the cleanliness of the beach was identified as one of the three most important aspects when choosing a beach. This is further confirmed by the motives, since motive 2 measured the quality of the beach in terms of aspects such as cleanliness. It is the motive with the second-highest mean value and when the different clusters are compared, this motive scored high for all clusters except for locals (cluster 1). In addition, it is noteworthy that the two highest-spending clusters - mixed high spenders and foreigners - both prefer to go to Blue Flag beaches (90.3\% and 96.7\%, respectively). Motive 5 included Blue Flag as a motive for beach choice and the South African market scored significantly higher than any other cluster in terms of this motive. Cluster 2 scored the second highest.

This finding holds particular implications for all beach destinations worldwide. Beachgoers are becoming increasingly concerned with their environment; beaches that experience degradation or high levels of pollution will stand to lose, especially from the higher-spending segments of their market. Beach quality, water quality and a pristine beach environment need to be enhanced to ensure the survival of beach destinations.

\section{Conclusion}

Beaches are an essential part of many destinations' tourism offering. Given the importance thereof, it is surprising that very little research has been conducted on understanding the spending behaviour and profiling of beach tourists. Therefore, the purpose of this article was to apply expenditure-based segmentation to beach tourists visiting South African beaches with the aim to distinguish between various segments and their characteristics.

In summary, this research identified four segments of visitors to South African beaches, ranging from low-spending locals 
to high-spending, mixed-market beachgoers. There are distinct differences between the segments and besides some socio-demographic differences, their beach-going behaviour and motives for visiting the beach also differ. The South African beachgoer is typically a lower spender, using the beach for activities and sport, whereas the high-spending segments are mainly foreigners who prefer the beach for sunbathing and relaxation. Important to all segments are the environmental qualities of the beach in terms of both cleanliness and beach safety. To the high-spending segments, Blue Flag status of the beach is also much more important, pointing to the possible negative effects of beach pollution for beach destinations' sustainability.

South Africa is a country blessed with an ample supply of sandy beaches, making beach tourism one of the most lucrative tourism segments. However, for beach tourism to be sustainable, it requires that businesses (economy), the community and the environment should benefit. Although this article mainly focussed on the economic aspects, that is, what distinguishes higher-spending markets from lower spending markets, the results show that this cannot be separated from the environment. Well-managed beaches, where the environment is protected, attract higher-spending tourists, making it possible for the economies surrounding these beaches to thrive.

Based on the results, the article makes the following contributions: Firstly, it shows that not all beachgoers are the same - some are higher spenders than others and in terms of sustainability, it is important to attract the high spenders to the beach as well and to cater for their needs. Secondly, beach quality and the Blue Flag status of the beach are the most important motives for all beachgoers to South African beaches. Thirdly, the research shows that the two main threats to beach tourism and destinations, not only in South Africa, but globally, are (1) pollution of the oceans, and (2) global warming. Clean beaches with quality water attract tourists and the increased pollution and degradation of the world's oceans and seas pose a major threat to the sustainability of beach destinations. In addition, the risk of sunburn is paramount among beachgoers; therefore, increased temperatures due to global warming also signal risks to beach destinations, which will have to think creatively in addressing these concerns.

Future research should be conducted to (1) determine the impact of global warming on beach tourism; (2) identify management strategies to address beach and ocean pollution; and (3) determine the economic contribution of beach tourism to economies and therefore the potential loss in income and employment due to adverse events.

\section{Acknowledgement}

The authors would also like to thank the reviewers for the constructive comments that helped shape the article.

\section{Competing interests}

The authors declare that they have no financial or personal relationships that may have inappropriately influenced them in writing this article.

\section{Authors' contributions}

The article was conceptualised and executed by both authors.

\section{Funding information}

This work is based on research supported by the National Research Foundation of South Africa under Grant: UID 85625 .

\section{Disclaimer}

The Grant holder (NRF) acknowledges that opinions, Findings and conclusions or recommendations are that of the author and that the NRF accepts no liability whatsoever in this regard.

\section{References}

Alegre, J. \& Juaneda, C., 2006, 'Destination loyalty: Consumers' economic behavior', Annals of Tourism Research 33(3), 684-706. https://doi.org/10.1016/j.annals. 2006.03.014

Botha, K., Slabbert, E., Rossouw, R. \& Viviers, P.A., 2011, 'Expenditure-based segmentation of visitors to Aardklop National Arts Festival', South African Theatre Journal 25(2), 142-166. https://doi.org/10.1080/10137548.2011.639168

Brida, J.G. \& Scuderi, R., 2013, 'Determinants of tourist expenditure: A review of microeconometric models', Tourism Management Perspectives 6, 28-40. https:// doi.org/10.1016/j.tmp.2012.10.006

Cal, L.A., Hong, G. \& Morrison, A.M., 1995, 'Household expenditure patterns for tourism products and services', Journal of Travel and Tourism Marketing 4(4), 15-40. https://doi.org/10.1300/J073v04n04_02

Cannon, T.F. \& Ford, J., 2002, 'Relationship of demographic and trip characteristics to visitor spending: An analysis of sport travel visitors across time', Tourism Economics 8(3), 263-271. https://doi.org/10.5367/000000002101298106

Craggs, R. \& Schofield, P., 2009, 'Expenditure-based segmentation and visitor profiling at The Quays in Salford, UK, Tourism Economics 15(1), 243-260. https://doi. org/10.5367/000000009787536753

Dickson, P.R. \& Ginter, J.L., 1987, 'Market segmentation, product differentiation, and marketing strategy', Journal of Marketing 51(2), 1--10. https://doi.org/10.1177/ 002224298705100201

Dixon, A.W., Backman, S., Backman, K. \& Norman, W., 2012, 'Expenditure-based segmentation of sport tourists', Journal of sport and tourism 17(1), 5-21. https:// doi.org/10.1080/14775085.2011.635017

Downward, P. \& Lumsdon, L., 2004, 'Tourism transport and visitor spending: A study in the North York Moors National Park, UK', Journal of Travel Research 42(4), 415-420. https://doi.org/10.1177/0047287504263038

Field, A., 2009, Discovering statistics using SPSS, 3rd edn., Sage Publishing Ltd: London, Thousand Oaks.

Frechtling, D.C., 2006, 'An assessment of visitor expenditure methods and models', JournalofTravelResearch20(1),1-10.https://doi.org/10.1177/0047287506288877

Harris, L.R., Nel, R. \& Schoeman, D.S., 2011, 'Mapping beach morphodynamics remotely: A novel application tested on South African sandy shores', Estuarine, Coastal and Shelf Science 92(1), 78-89. https://doi.org/10.1016/j.ecss.2010. 12.013

Hong, G.S., Fan, J.X., Palmer, L. \& Bhargava, V., 2005, 'Leisure travel expenditure patterns by family life cycle stages', Journal of Travel and Tourism Marketing 18(2), 15-30. https://doi.org/10.1300/J073v18n02_02

Houston, J.R., 2002, 'The economic value of beaches -2002 update', Shore \& Beach 70(1), 9-12.

Houston, J.R., 2008, 'The economic value of beaches: A 2008 update', Shore and Beach 76(3), 22-26.

James, R.J., 2000, 'From beaches to beach environments: Linking the ecology, humanuse and management of beaches in Australia,' Ocean \& Coastal Management 43(6), 495-514. https://doi.org/10.1016/S0964-5691(00)00040-5

Jang, S.C., Bai, B., Hong, G.S. \& O'Leary, J.T., 2004, 'Understanding travel expenditure patterns: A study of Japanese Pleasure Travelers to the United States by income level', Tourism Management 25(3), 331-341. https://doi.org/10.1016/S02615177(03)00141-9 
Jang, S.C., Morrison, A.M. \& O'Leary, J.T., 2002, 'Benefit segmentation of Japanese Pleasure Travelers to the USA and Canada: Selecting target markets based on the profitability and risk of individual market segments', Tourism Management 23(4) profitability and risk of individual market segments', Tourism
367-378. https://doi.org/10.1016/S0261-5177(03)00141-9

Kastenholz, E., 2005, Analysing determinants of visitor spending for the rural tourist market in North Portugal', Tourism Economicsm 11(4), 555-569. https://doi.org/ 10.5367/000000005775108728

Kruger, M., 2009, Spending behaviour of visitors to the Klein Karoo National Arts Festival, MA diss, North West University: Potchefstroom, South Africa.

Kruger, M., 2010, 'A critical evaluation of market segmentation at National Arts Festivals in South Africa', PhD thesis, North West University, Potchefstroom, South Africa.

Kruger, M., Saayman, M. \& Ellis, S.M., 2010a, 'Does loyalty pay? First-time versus repeat visitors at a national arts festival', Southern African Business Review 14(1), 79-104. https://doi.org/10.4102/ac.v14i1.220

Kruger, M., Saayman, M. \& Saayman, A., 2010b, 'Expenditure-based segmentation of visitors to the Tsitsikamma National Park', Acta Commercii 10(1), 137-149. https://doi.org/10.4102/ac.v10i1.123

Kuo, H.I. \& Lu, C.L., 2013, 'Expenditure-based segmentation: Application of quantile regression to analyse the travel expenditures of baby boomer households', regression to analyse the travel expenditures of baby boomer household
Tourism Economics 19(6), 1429-1441. https://doi.org/10.5367/te.2013.0268

Leatherman, S.P., 1997, 'Beach rating: A methodological approach', Journal of Coastal Research 13(1), 253-258.

Lee, H., 2001, 'Determinants of recreational boater expeditions on trips', Tourism Management 22(6), 659-667. https://doi.org/10.1016/S0261-5177(01)00033-4

Lee, C., Lee, Y., Bernhard, B. \& Yoon, Y., 2006, 'Segmenting casino gamblers by motivation: A cluster analysis of Korean gamblers', Tourism Management 27(5), 856-866. https://doi.org/10.1016/j.tourman.2005.05.009

Letho, X.Y., Cal, L.A., O'Leary, J.T. \& Huan, T., 2004, 'Tourist shopping preferences and expenditure behaviours: The case of the Taiwanese Outbound Market', Journal of Vacation Marketing 10(4), 320-332. https://doi.org/10.1177/13567667040 1000404

Lima, J., Eusébio, C. \& Kastenholz, E., 2012, 'Expenditure-based segmentation of a mountain destination tourist market', Journal of Travel and Tourism Marketing 29(7), 695-713. https://doi.org/10.1080/10548408.2012.720155

Lucrezi, S. \& Saayman, M., 2014, 'Beachgoers' demands vs. Blue flag aims in South Africa', Journal of Coastal Research 31(6), 1478-1488. https://doi.org/10. 2112/JCOASTRES-D-14-00062.1

Mehmetoglu, M., 2007, 'Nature-based tourists: The relationship between their trip expenditures and activities', Journal of Sustainable Tourism 15(2), 200-215. https://doi.org/10.2167/jost642.0

Mok, C. \& Iverson, T.J., 2000, 'Expenditure-based segmentation: Taiwanese Tourists to Guam', Tourism Management 21(3), 299-305. https://doi.org/10.1016/S02615177(99)00060-6

Norušis, M.J., 2012, IBM SPSS statistics 19 statistical procedures companion, Pearson, Upper Saddle River, NJ.

Oppermann, M., 1996, 'Visitation of tourism attractions and tourist expenditure patterns: Repeat versus first-time visitors', Asia Pacific Journal of Tourism Research 1(1), 61-68. https://doi.org/10.1080/10941669708721964

Perez, E.A. \& Sampol, J.C., 2000, 'Tourist expenditure for mass tourism markets', Annals of Tourism Research 27(3), 624-637. https://doi.org/10.1016/S01607383(99)00101-2

Phillips, M.R. \& House, C., 2009, 'An evaluation of priorities for beach tourism: Case studies from South Wales, UK', Tourism Management 30(2), 176-183. https://doi. studies from South Wales, UK', Tourism

Pizam, A. \& Reichel, A., 1979, 'Big spenders and little spenders in U.S. tourism', Journa of Travel Research 18(1), 42-43. https://doi.org/10.1177/004728757901800108

Pouta, E., Neuvonen, M. \& Sievanen, T., 2006, 'Determinants of nature trip expenditures in Southern Finland-implications for nature tourism development Scandinavian Journal of Hospitality and Tourism 6(2), 118-135. https://doi.org/ 10.1080/15022250600658937

Saayman, A. \& Saayman, M., 2009, 'Socio-demographic and behavioural determinants of visitor spending at the Kruger National Park in South Africa', South African Journal for Economic and Management Sciences 12(4), 493-512. https://doi. org/10.4102/sajems.v12i4.191
Saayman, M. \& Saayman, A., 2012, 'Determinants of spending: An evaluation of three major sporting events', International Journal of Tourism Research 14(2), 124-138. https://doi.org/10.1002/jtr.841

Saayman, M., 2017, 'Blue growth and tourism', Keynote address at the 6th IATE conference, Rimini, Italy, June 2017.

Saayman, M. \& Krugel, W., 2009, 'Determinants of visitors spending at the Wacky Wine Festival', Journal of Economics and Financial Sciences 3(2), 153-170. https:// doi.org/10.1111/j.1435-5957.2006.00094 x

Saayman, M., Kruger, M., Slabbert, E., Saayman, A. \& Rootenberg, C., 2009, The socioeconomic impact of visitors to the Wacky Wine Festival, Institute for tourism and leisure studies: Potchefstroom, South Africa, Research Report.

Saayman, M. \& Saayman, A., 2006, 'Does the location of arts festivals matter for the economic impact?', Papers in Regional Science 85(4), 569-584. https://doi. org/10.1111/j.1435-5957.2006.00094.x

Saayman, M. \& Saayman, A., 2018, 'Are there economic benefits from marine protected areas? An analysis of scuba diver expenditure', European Journal of Tourism Research 19, 23-39.

Saayman, M., Saayman, A. \& Joubert, E., 2012, 'Expenditure-based segmentation of visitors to the Wacky Wine festival', Tourism Recreation Research 37(3), 215-225. https://doi.org/10.1080/02508281.2012.11081710

Saayman, M., Van der Merwe, P. \& Pienaar, J., 2008, 'Expenditure based segmentation of tourists to the Kruger National Park', Acta Academica 4(3), 49-58.

Seiler, V.L., Seiler, M.J., Hsieh, C. \& Hsieh, S., 2002, 'Modeling travel expenditures for Taiwanese tourism', Journal of Travel and Tourism Marketing 13(4), 47-59. https://doi.org/10.1300/J073v13n04_03

Shani, A., Wang, Y., Hutchinson, J. \& Lai, F., 2010, 'Applying expenditure-based segmentation on special-interest tourists: The case of Golftravelers', Journal of Travel Research 49(3), 337-350. https://doi.org/10.1177/0047287509 346852

Shih, M.-Y., Jheng, J.-W. \& Lai, L.-F., 2010, 'A two-step method for clustering mixed categorical and numeric data', Tamkang Journal of Science and Engineering 13(1), 11-19.

Snowball, J.D. \& Willis, K.G., 2006, 'Estimating the marginal utility of different sections of an arts festival: The case of visitors to the South African National Arts Festival', Leisure Studies 25(1), 43-56. https://doi.org/10.1080/0261436052000 330410

Soteriades, M.D. \& Arvanitis, S.E., 2006, 'Expenditure patterns by travel party size: British and German tourists on Crete, Greece', Anatolia: An International Journal of Tourism and Hospitality Research 17(2), 169-187. https://doi.org/10.1080/130 of Tourism and Hospitain

Spotts, D.M. \& Mahoney, E.M., 1991, 'Segmenting visitors to a destination region based on the volume of their expenditures', Journal of Travel Research 29(1), 24-31. https://doi.org/10.1177/004728759102900405

Sung, H.Y., Morrison, A.M. \& O'Leary, J.T., 2000, 'Segmenting the adventure travel market by activities: From the North American industry providers' perspective', Journal of Travel and Tourism Marketing 9(4), 1-19. https://doi.org/10.1300/ J073v09n04_01

Thrane, C., 2002, 'Jazz festival visitors and their expenditures: Linking spending patterns to musical interest', Journal of Research 40(3), 281-286. https://doi. org/10.1177/0047287502040003006

Tudor, D.T. \& Williams, A.T., 2006, 'A rationale for beach selection by the public on the coast of Wales, UK', Area 38(2), 153-164. https://doi.org/10.1111/j.1475-4762. 2006.00684.x

Wang, D., 2004, 'Tourist behaviour and repeat visitation to Hong Kong', Tourism Geographies 6(1), 99-118. https://doi.org/10.1080/14616680320001722355

Wang, Y., Rompf, P., Severt, D. \& Peerapatdit, N., 2006, 'Examining and identifying the determinants of travel expenditure patterns', International Journal of Tourism Research 8(5), 333-346. https://doi.org/10.1002/jtr.583

Wilton, J.J. \& Nickerson, N.P., 2006, 'Collecting and using visitor spending data', Journal of Travel Research 45(1), 17-25. https://doi.org/10.1177/00472875062 88875

Woodside, A.G., Cook, V.J. \& Mindak, W., 1987, 'Profiling the heavy traveller segment', Journal of Travel Research 25(3), 9-15. https://doi.org/10.1177/004728758 702500402 


\section{Appendix 1}

TABLE 1-A1: Summary statistics of the sample.

\begin{tabular}{lccccc}
\hline Variable & $\boldsymbol{N}$ & Minimum & Maximum & Mean & $\begin{array}{c}\text { Standard } \\
\text { deviation }\end{array}$ \\
\hline Age & 551 & 14 & 78 & 34.05 & 12.90 \\
Travel group size & 532 & 1 & 30 & 3.63 & 3.64 \\
Nights spent at the location & 433 & 0 & 365 & 14.09 & 36.74 \\
Spending per person & 598 & 0 & 115000 & 7075.91 & 12981.20 \\
Number of summer visits & 522 & 0 & 270 & 21.05 & 54.63 \\
Number of winter visits & 412 & 0 & 243 & 10.05 & 26.77 \\
\hline
\end{tabular}

TABLE 2-A1: Frequency description of the sample.

\begin{tabular}{|c|c|c|c|}
\hline Variables & Characteristics & Frequency & Per cent \\
\hline \multirow[t]{2}{*}{ Gender } & Male & 240 & 40.885 \\
\hline & Female & 347 & 59.114 \\
\hline \multirow[t]{3}{*}{ Language } & English & 290 & 49.152 \\
\hline & Afrikaans & 110 & 18.644 \\
\hline & Other & 190 & 32.203 \\
\hline \multirow[t]{7}{*}{ Education } & No school & 10 & 1.721 \\
\hline & Still in School & 29 & 4.991 \\
\hline & Matric & 118 & 20.309 \\
\hline & Diploma/Degree & 202 & 34.767 \\
\hline & Post-graduate & 119 & 20.481 \\
\hline & Professional & 86 & 14.802 \\
\hline & Other & 17 & 2.925 \\
\hline \multirow[t]{5}{*}{ Marital status } & Single & 320 & 53.691 \\
\hline & Married/Partner & 228 & 38.255 \\
\hline & Divorced & 21 & 3.523 \\
\hline & Widow/er & 9 & 1.510 \\
\hline & Other & 18 & 3.020 \\
\hline \multirow[t]{5}{*}{ Occupation } & Student & 119 & 20.272 \\
\hline & Paid worker & 383 & 65.247 \\
\hline & Unpaid worker & 16 & 2.725 \\
\hline & Unemployed & 32 & 5.451 \\
\hline & Retired & 37 & 6.303 \\
\hline \multirow[t]{2}{*}{ Local resident } & No & 451 & 76.182 \\
\hline & Yes & 141 & 23.817 \\
\hline \multirow[t]{10}{*}{ Origin } & Foreigner (non-RSA) & 211 & 35.284 \\
\hline & Western Cape (WC) & 120 & 20.066 \\
\hline & Gauteng & 87 & 14.548 \\
\hline & Eastern Cape (EC) & 73 & 12.207 \\
\hline & Free State (FS) & 9 & 1.505 \\
\hline & Kwazulu-Natal (KZN) & 64 & 10.702 \\
\hline & Mpumalanga (MP) & 8 & 1.337 \\
\hline & Northern Cape (NC) & 6 & 1.003 \\
\hline & North-West (NWP) & 12 & 2.006 \\
\hline & Limpopo (LP) & 8 & 1.337 \\
\hline
\end{tabular}

TABLE 3-A1: Summary of analysis of variance results.

\begin{tabular}{lcc}
\hline Variable & $\boldsymbol{F}$ & Sig. \\
\hline Age & 2.663 & 0.047 \\
Group & 0.529 & 0.663 \\
Nights & 30.284 & 0.000 \\
Summer visits & 21.283 & 0.000 \\
Winter visits & 14.934 & 0.000 \\
Motivation 1 & 23.747 & 0.000 \\
Motivation 2 & 1.540 & 0.203 \\
Motivation 3 & 1.365 & 0.252 \\
Motivation 4 & 1.592 & 0.190 \\
Motivation 5 & 3.748 & 0.011 \\
Motivation 6 & 1.044 & 0.373 \\
\hline
\end{tabular}

TABLE 4-A1: Summary of chi-squared and Cramer's V test results.

\begin{tabular}{|c|c|c|c|c|}
\hline \multirow[t]{2}{*}{ Variables } & \multicolumn{2}{|c|}{ Chi-square } & \multicolumn{2}{|c|}{ Cramer's V } \\
\hline & Value & Sign & Value & Sign \\
\hline Blue Flag & 57.242 & 0.000 & 0.311 & 0.000 \\
\hline Gender & 1.740 & 0.628 & 0.055 & 0.628 \\
\hline Sunbathing & 51.599 & 0.000 & 0.295 & 0.000 \\
\hline Swimming & 35.188 & 0.000 & 0.244 & 0.000 \\
\hline Surfing & 15.585 & 0.001 & 0.162 & 0.001 \\
\hline Walking & 33.275 & 0.000 & 0.237 & 0.000 \\
\hline Sport & 8.738 & 0.033 & 0.121 & 0.033 \\
\hline Fishing & 15.502 & 0.001 & 0.162 & 0.001 \\
\hline Relaxation & 7.199 & 0.066 & 0.110 & 0.066 \\
\hline Need_cleanliness & 4.238 & 0.237 & 0.085 & 0.237 \\
\hline Need_safety & 20.722 & 0.000 & 0.187 & 0.000 \\
\hline Need_conditions & 16.777 & 0.001 & 0.168 & 0.001 \\
\hline Need_activities & 5.741 & 0.125 & 0.098 & 0.125 \\
\hline Need_non-crowding & 10.454 & 0.015 & 0.133 & 0.015 \\
\hline Need_child friendliness & 5.080 & 0.166 & 0.093 & 0.166 \\
\hline Need_amenities & 3.370 & 0.338 & 0.075 & 0.338 \\
\hline Need_people & 3.222 & 0.359 & 0.074 & 0.359 \\
\hline Need_access & 2.796 & 0.424 & 0.069 & 0.424 \\
\hline Risk_crowding & 1.984 & 0.576 & 0.058 & 0.576 \\
\hline Risk_theft & 13.929 & 0.003 & 0.153 & 0.003 \\
\hline Risk_injury & 1.897 & 0.594 & 0.057 & 0.594 \\
\hline Risk_sun & 21.901 & 0.000 & 0.192 & 0.000 \\
\hline Risk_drowning & 6.740 & 0.081 & 0.107 & 0.081 \\
\hline Risk_sharks & 5.716 & 0.126 & 0.098 & 0.126 \\
\hline Risk_conditions & 10.369 & 0.016 & 0.132 & 0.016 \\
\hline Risk_safety & 17.393 & 0.001 & 0.171 & 0.001 \\
\hline
\end{tabular}

